\title{
Vancomycin: the need to suit serum concentrations in hemodialysis patients
}

\begin{abstract}
The vancomycin dose for hemodialysis (HD) patients should be adjusted by monitoring drug serum concentrations. However, this procedure is not available in most health services in Brazil, which usually adopts protocols based on published studies. The trials available are controversial, and several have not been conducted with current dialyzers. This study aimed at assessing the suitability of vancomycin serum concentrations in HD patients at a public hospital. Blood samples of HD patients were collected from November 2006 to May 2007, at time intervals of 48, 96, 120, or 168 hours after vancomycin administration. Drug measurement was performed with polarized light immunofluorescence. Approximately $86 \%$ of trough vancomycin serum concentrations were below the recommended value, indicating exposure to subtherapeutic doses and a higher risk for selecting resistant microorganisms.
\end{abstract}

Keywords: vancomycin, chronic renal failure, hemodialysis.

[Braz J Infect Dis 2010;14(2):203-208]@Elsevier Editora Ltda.

\section{INTRODUCTION}

Vancomycin, an amphoteric and high-molecular-weight complex tricyclic glycopeptide antibiotic, available in the form of water-soluble hydrochloride, is often used for treating severe hospital infections. ${ }^{1}$ Vancomycin concomitantly inhibits the cell wall synthesis of susceptible microorganisms or bacteria, altering cytoplasm membrane permeability and interfering with RNA synthesis. ${ }^{2}$ Its most significant adverse effects are ototoxicity and nephrotoxicity. Marinho (2005) has reported that approximately $30 \%$ of patients have experienced some adverse reaction to vancomycin, such as renal failure (18\%), thrombocytopenia $(7 \%)$, neutropenia $(2 \%)$, red man syndrome (2\%), and ototoxicity ( $1 \%){ }^{3}$

The increased use of vancomycin has been attributed to the increase of nosocomial infections caused by methicillin-resistant Staphylococcus aureus (MRSA), which increased from $2 \%$ in 1974 to more than $50 \%$ in $2000 .{ }^{4}$

Bacterial infections most often occur in hemodialysis (HD) patients. This is most probably related to frequent violation of normal skin and mucosa barriers than to immune dysfunction. Bacterial infections in HD patients progress more rapidly and resolve less promptly than those in non-uremic patients. ${ }^{5}$
Venous access site is the source of $50 \%$ to $80 \%$ of the bacteremia episodes in dialysis patients. Bacteremia can lead to endocarditis, meningitis, osteomyelitis, paraspinal abscess, or formation of septic embolus. Arteriovenous fistulas do not have an exit site, thus being associated with lower infection rates. ${ }^{6}$

In HD patients, infections caused by Grampositive bacteria can be treated with vancomycin, mainly due to its activity against most Gram-positive pathogens, especially MRSA. Moreover, vancomycin has a long half life in renal failure, which allows using intermittent doses regimes. ${ }^{7}$ However, the pharmacokinetic characteristics of this antibiotic should be respected to maintain adequate levels, minimize the appearance of resistant strains, and avoid toxicity. ${ }^{8}$ Changes in renal function associated with normal aging or with diseases can have a deep effect on the pharmacology of antibiotics, which require their doses to be adjusted. ${ }^{9,10,11}$

The amount of vancomycin removed by $\mathrm{HD}$ is negligible when conventional dialyzers are used; however, when using high-flow membrane dialyzers, a significant reduction in vancomycin levels can occur. ${ }^{5,11}$

Measurement of vancomycin serum levels in patients with renal failure is required to as-
Authors

Lívia Luize Marengo $^{1}$ Fernando de Sá Del Fiol ${ }^{2}$ Sara de Jesus Oliveira ${ }^{2}$ Celso Nakagawa ${ }^{3}$ Eduardo Leite Croco ${ }^{3}$ Silvio Barberato-Filho ${ }^{2}$ Marcela Pellegrini Peçanha ${ }^{4}$

Douglas Felix da Silva ${ }^{2}$ Maria Inês de Toledo ${ }^{2,5}$

${ }^{1}$ Pharmacy School of Universidade de Sorocaba PIBIC-CNPq

${ }^{2}$ Researcher of the Reference Center on Information About Antibiotics (CRIA) of Universidade de Sorocaba ${ }^{3}$ Conjunto Hospitalar de Sorocaba

${ }^{4}$ Faculdade de Ciências Médicas e da Saúde - PUC São Paulo

${ }^{5}$ Faculdade de Tecnologia de Sorocaba

Submitted on: 02/16/2009 Approved on: 10/15/2009

Correspondence to: Profa. Dra. Maria Inês de Toledo

Rua Silvério E. Oliveira, 160 - Jd. Saira

Sorocaba - São Paulo Brazil

CEP: 18085-645

Phone: 551532385266

E-mail: mitoledo@

yahoo.com

This study received financial support from the Conselho Nacional de Desenvolvimento Científico e Tecnológico (CNPq) 
sure adequate bactericidal levels. According to Lentino and Leehey (2001), vancomycin maximum and minimum serum levels are $30-40 \mu \mathrm{g} / \mathrm{mL}$ and $5-10 \mu \mathrm{g} / \mathrm{mL}$, respectively. ${ }^{5}$

Due to the high variability of the minimum inhibitory concentrations (MIC) for vancomycin-susceptible staphylococcus strains, a recent study has recommended that vancomycin levels range from 5 to 10 times the MIC value. $^{12}$

The suggested dose of vancomycin for HD patients is $15 \mathrm{mg} / \mathrm{kg}$ every 7 to 10 days. ${ }^{13}$ However, when high-flow membranes are used in HD, additional vancomycin doses are recommended at every HD session..$^{14}$ Lentino and Leehey (2001) have recommended that the interval between vancomycin doses in HD patients should be enlarged, but treatment should begin with an attack dose of $20 \mathrm{mg} / \mathrm{kg}$ and continued with subsequent doses of $15 \mathrm{mg} / \mathrm{kg}$ every seven days after the HD session. ${ }^{5}$

Other authors have suggested changes in dosing and interval according to the administration regimen and the type of dialyzer used. However, reviewing studies on the pharmacokinetics of vancomycin in HD patients showed several limitations, different conclusions and suggestions of dose adjustment could be identified as shown in Table 1. The divergences and limitations of the studies published have motivated the conduction of this study that aimed at monitoring the serum levels of vancomycin in HD patients and checking if the concentrations were adequate.

\section{METHOD}

The study was approved by the Research Ethics Committee of the Universidade de Sorocaba (Protocol 001/05) and by the Teaching and Research Committee of the Conjunto Hospitalar de Sorocaba (state of São Paulo), a state public hospital that attends approximately $120 \mathrm{HD}$ patients. All patients included in this study used vancomycin during the period studied (from November 2006 to May 2007) and provided written informed consent. The exclusion criteria were as follows: report of allergy to vancomycin, liver disease, or previous use of vancomycin up to 15 days before sample collection.

Data collection from medical records included the following: gender, age, origin, and ethnicity. The results of culture and antibiogram were obtained from the Hospital Infection Control Service of the Conjunto Hospitalar de Sorocaba.

Vancomycin (Vancocina CP - ABL Antibióticos do Brasil) was given in dose of $1 \mathrm{~g}$ diluted into $100 \mathrm{~mL}$ of $0.9 \%$ sodium chloride solution infused during the last hour of HD, according to the service's protocol, which recommends the administration of $1 \mathrm{~g}$ every seven days. Blood samples were collected by the nurse team in tubes containing ethylene diamine tetraacetic acid (EDTA) for hemogram and in dry tubes for measuring vancomycin and albumin. Then, they were centrifuged and frozen. The collections for measuring vancomycin were obtained in single samples at the time points $48,96,120$ or 168 hours after administering the first dose of the drug.

Hemogram was performed in the automated ABX Pentra60 ${ }^{\circledR}$ device, at the Instituto Diagnóstico de Sorocaba. The endpoint colorimetric method was used for measuring albumin with a kit containing bromocresol green (BCG) of Laborlab, at the Universidade de Sorocaba. Vancomycin serum levels were measured by using $150 \mu \mathrm{L}$ of serum and polarized light immunofluorescence with monoclonal antibodies (ABBOTT Laboratories kits) in the automated AxSym ${ }^{\circledR}$ device (ABBOTT), in the sector of serology of the Hemonúcleo of the Conjunto Hospitalar de Sorocaba.

The results were reported regarding the percentage of patients with inadequate serum concentrations and need for dose adjustment. Statistical analyses (ANOVA) were performed in the correlation of the results of vancomycin and albumin concentrations and hematocrit levels. The significance level of 5\% was adopted.

\section{RESULTS}

The study comprised 17 patients, five of whom used vancomycin more than once during the period studied, at a mean interval of 72 days, adding up to the collection of 22 samples. Their mean age was $56.9 \pm 6.0$ years. Most patients $(56 \%)$ were female, married $(65 \%)$, white $(65 \%)$, and came from the municipalities of the Sorocaba region (59\%).

The following clinical conditions related to HD procedure stand out: double-lumen catheter as the most common venous access (65\%); dialysis capillary reuse time ranging from 1-19 days, median of three days; association of diabetes mellitus and arterial hypertension as the most frequent etiology of chronic renal failure (41\%); mean HD time of 16 months. All patients used polysulfone dialyzer membrane.

Patients' laboratory data presented in Table 2 showed that albumin (reference values: $3.4-4.8 \mathrm{~g} / \mathrm{dL})^{21}$ and hematocrit (reference values: women: $39-49 \%$ and men: $35-45 \%)^{21}$ were below normal values, but compatible with the setting of chronic renal failure. Neither statistical difference between groups (ANOVA), nor correlation between the patient's plasma level of albumin and serum concentration of vancomycin were observed ( $\mathrm{p}>0.05)$.

Regarding to vancomycin serum concentrations, no statistical difference (ANOVA, $\mathrm{p}>0.05$ ) between the values of the four groups was observed (Table 2). However, at least $14 \%$ of the results were inadequate when considering the minimum trough concentration greater than $5 \mu \mathrm{g} / \mathrm{mL}$, and $86 \%$ were inadequate when considering the minimum trough concentration greater than $10 \mu \mathrm{g} / \mathrm{mL}$ (Figure 1).

Staphylococci were identified in one third of the cases, and approximately $25 \%$ of the microorganisms isolated 
Table 1. Limitations, objectives and conclusions of the major studies on monitoring vancomycin in hemodialysis.

\begin{tabular}{|c|c|c|c|}
\hline Reference & Limitations of the study & Goal & Major conclusions \\
\hline $\begin{array}{l}\text { Nielsen et al. } \\
\qquad(1975)^{15}\end{array}$ & $\begin{array}{l}\text { Number of patients (four) } \\
\text { undergoing hemodialysis } \\
\text { with no infection }\end{array}$ & $\begin{array}{l}\text { To check the renal excretion } \\
\text { rate in several degrees of } \\
\text { renal failure }\end{array}$ & $\begin{array}{l}\text { For anuric patients, } 7 \% \text { of } \\
\text { the usual maintenance dose } \\
\text { per unit of time are } \\
\text { recommended }\end{array}$ \\
\hline $\begin{array}{l}\text { Masur et al. } \\
(1982)^{16}\end{array}$ & $\begin{array}{l}\text { They do not specify } \\
\text { the dialyzer used }\end{array}$ & $\begin{array}{l}\text { To assess toxicity and } \\
\text { pharmacokinetics } \\
\text { in prolonged treatment } \\
\text { (accumulation) }\end{array}$ & $\begin{array}{l}\text { Large variation in peak and } \\
\text { trough concentration (to } \\
\text { monitor). Negative cultures in } \\
\text { the initial } 48 \text { hours of therapy. } \\
\text { Low toxicity }\end{array}$ \\
\hline $\begin{array}{l}\text { Gonzáles-Martin } \\
\text { et al. }(1996)^{17}\end{array}$ & $\begin{array}{l}\text { Small number of patients } \\
\text { with infection, several topographies } \\
\text { and unstable patients (sepsis). } \\
\text { They also report peak concentration } \\
\text { above the limit of toxicity }\end{array}$ & $\begin{array}{l}\text { To correlate renal function } \\
\text { and vancomycin } \\
\text { concentration }\end{array}$ & $\begin{array}{c}\text { For patients with creatinine } \\
\text { clearance }<10 \mathrm{~mL} / \mathrm{min}^{-1}, \\
\text { vancomycin doses of } 1 \mathrm{~g} \text { every } \\
\text { seven days are suitable }\end{array}$ \\
\hline $\begin{array}{l}\text { Zoer; Schrander- } \\
\text { Van der Meer; } \\
\text { Van Dorp } \\
(1997)^{18}\end{array}$ & Patients with no infection & $\begin{array}{c}\text { To check vancomycin } \\
\text { clearance with two types } \\
\text { of dialyzers }\end{array}$ & $\begin{array}{l}\text { Vancomycin clearance does not } \\
\text { depend on HD flow. } \\
\text { Recommendation: one gram } \\
\text { initially }+500 \text { mg during each } \\
\text { subsequent HD session }\end{array}$ \\
\hline $\begin{array}{l}\text { Foote et al. } \\
\qquad(1998)^{19}\end{array}$ & $\begin{array}{l}\text { Five patients } \\
\text { with no infection }\end{array}$ & $\begin{array}{l}\text { To assess the pharmacokinetics } \\
\text { of high doses of vancomycin } \\
\text { in F80-Fresenius polysulfone } \\
\text { membrane }\end{array}$ & $\begin{array}{l}25 \mathrm{mg} / \mathrm{kg} \text { during HD } \\
\text { determine adequate } \\
\text { concentration for up to } \\
\text { seven days and subsequent } \\
\text { doses should be adjusted } \\
\text { according to serum } \\
\text { concentration }\end{array}$ \\
\hline $\begin{array}{l}\text { Lucksiri et al. } \\
\qquad(2002)^{20}\end{array}$ & Patients with no infection & $\begin{array}{l}\text { To determine the amount of } \\
\text { vancomycin removed by the } \\
\text { CAHP- } 210 \text { dialyzer }\end{array}$ & $\begin{array}{l}\text { Vancomycin administered } \\
\text { during the last hour of HD } \\
\text { results in a } 24 \% \text {-lower } \\
\text { concentration than when } \\
\text { administered after HD }\end{array}$ \\
\hline $\begin{array}{l}\text { Mason et al. } \\
\qquad(2003)^{7}\end{array}$ & Patients with no infection & $\begin{array}{l}\text { To compare three regimens } \\
\text { of vancomycin dosing }\end{array}$ & $\begin{array}{l}\text { Administration of } 30 \mathrm{mg} / \mathrm{kg} \\
\text { during HD is equivalent to } \\
\text { administration of } 15 \mathrm{mg} / \mathrm{kg} \\
\text { after HD }\end{array}$ \\
\hline
\end{tabular}

Figure 1: Graphic representation of vancomycin measurement results in samples of patients with renal failure undergoing hemodialysis $(n=22)$. MRC $=$ minimum recommended concentration.

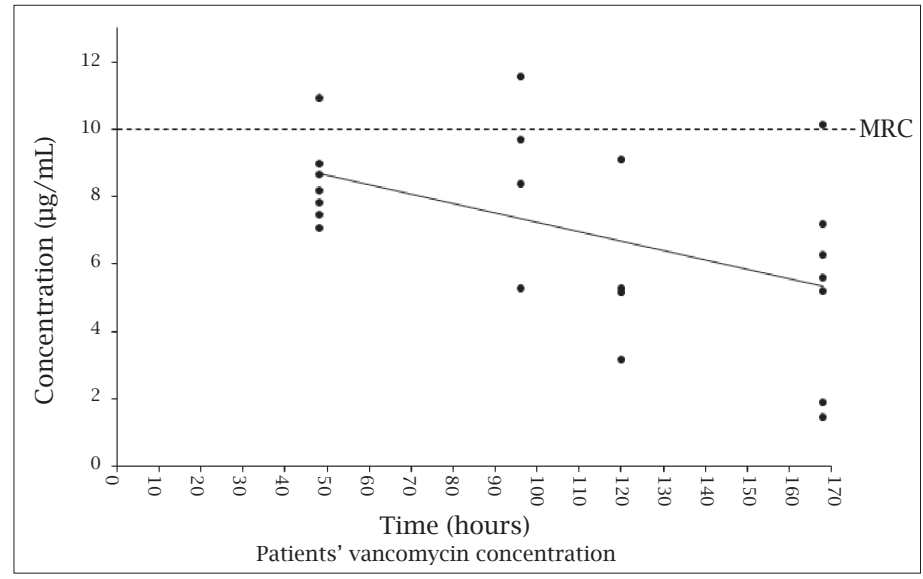


Table 2. Laboratory data and vancomycin measurement in samples $(n=22)$ of HD patients

\begin{tabular}{|c|c|c|c|c|c|c|}
\hline Groups & Samples & Patient & $\begin{array}{c}\text { Hematocrit } \\
\text { (\%) }\end{array}$ & $\begin{array}{l}\text { Total leukocytes } \\
\qquad\left(10^{3} / \mathrm{mm}^{3}\right)\end{array}$ & Albumin (g/dL) & $\begin{array}{c}\text { Vancomycin } \\
(\mu \mathrm{g} / \mathrm{mL})\end{array}$ \\
\hline & 1 & A & NI & NI & 2.67 & 7.80 \\
\hline Group 1 & 2 & B & NI & NI & 2.24 & 8.17 \\
\hline $48 \mathrm{~h}$ & 3 & $\mathrm{C}$ & NI & NI & 2.46 & 8.64 \\
\hline \multirow[t]{4}{*}{$\mathrm{n}=7$} & 4 & $\mathrm{D}^{*}$ & 26.10 & 5.70 & 2.35 & 8.94 \\
\hline & 5 & $\mathrm{E}$ & 20.40 & 6.90 & 2.78 & 7.44 \\
\hline & 6 & $F^{*}$ & 24.10 & 15.80 & 1.92 & 7.03 \\
\hline & 7 & G & 17.00 & 2.40 & 2.56 & 10.92 \\
\hline Mean \pm SD & & & $21.90 \pm 4.00$ & $7.70 \pm 5.70$ & $2.40 \pm 0.30$ & $8.40 \pm 1.30$ \\
\hline Group 2 & 8 & $\mathrm{H}$ & 22.20 & 16.80 & NI & 9.68 \\
\hline 96h & 9 & $I^{*}$ & 22.00 & 7.90 & 2.88 & 5.25 \\
\hline \multirow[t]{2}{*}{$\mathrm{n}=4$} & 10 & $\mathrm{~J}^{*}$ & NI & NI & 2.35 & 11.54 \\
\hline & 11 & G & 16.10 & 4.20 & 2.88 & 8.35 \\
\hline Mean \pm SD & & & $20.10 \pm 3.50$ & $9.60 \pm 6.80$ & $2.70 \pm 0.30$ & $8.70 \pm 2.60$ \\
\hline Group 3 & 12 & $\mathrm{C}$ & 27.10 & 6.90 & 3.20 & 3.13 \\
\hline $120 \mathrm{~h}$ & 13 & $\mathrm{~K}$ & 29.80 & 4.80 & 3.20 & 5.14 \\
\hline \multirow[t]{2}{*}{$\mathrm{n}=4$} & 14 & $\mathrm{~L}$ & 24.60 & 4.70 & 2.88 & 5.23 \\
\hline & 15 & A & 24.80 & 2.80 & 3.20 & 9.06 \\
\hline \multirow[t]{3}{*}{ Mean \pm SD } & & & $26.60 \pm 2.40$ & $4.80 \pm 1.70$ & $3.10 \pm 0.20$ & $5.60 \pm 2.50$ \\
\hline & 16 & $M^{*}$ & 32.20 & 6.40 & 3.31 & 1.86 \\
\hline & 17 & $\mathrm{~L}$ & 31.60 & 5.60 & 3.31 & 1.42 \\
\hline Group 4 & 18 & $\mathrm{D}$ & 18.00 & 3.90 & 2.56 & 5.19 \\
\hline $168 \mathrm{~h}$ & 19 & $\mathrm{~N}$ & 20.50 & 6.40 & 3.52 & 6.23 \\
\hline \multirow[t]{3}{*}{$\mathrm{n}=7$} & 20 & $\mathrm{O}$ & 20.00 & 1.90 & 3.74 & 10.13 \\
\hline & 21 & $\mathrm{P}$ & 24.30 & 10.40 & 2.78 & 5.56 \\
\hline & 22 & $Q^{*}$ & NI & NI & 2.78 & 7.16 \\
\hline Mean \pm SD & & & $24.40 \pm 6.10$ & $5.80 \pm 2.80$ & $3.10 \pm 0.40$ & $5.40 \pm 3.00$ \\
\hline
\end{tabular}

*Patients with confirmed diagnosis of staphylococcal infection.

$\mathrm{SD}=$ standard deviation; $\mathrm{NI}=$ no information

were Staphylococcus aureus. Of those, 50\% were oxacillinresistant, and $100 \%$ were sensitive to vancomycin.

\section{DISCUSSION}

Several studies used for establishing the current empirical protocols of vancomycin dosing in patients with renal failure undergoing HD are outdated with regards to dialysis equipments. The manufacturer of the reference drug (Vancocin ${ }^{\circledR}$ ) reports that it is not dialyzable and its half life is 7.5 days in patients with severe renal failure. However, the various trials have different case series and several limitations, such as the small number of patients, unstable patients (with sepsis), patients with no infection, and patients using different types of dialyzers. Launay-Vaucher et al. (2002) have discussed the use of several dialysis membranes and systems aiming at establishing protocols for monitoring serum concentration. In fact, that aspect has been seldom explored in the international literature, since most hospitals in developed countries monitor vancomycin concentration in patients at risk (neonates, patients with large burns, patients with renal failure, and the elderly). In Brazil, however, few hospitals do this on a regular basis. The cost of that automated test is considered a limiting factor and is equivalent to the mean price of one drug vial. ${ }^{10}$

Currently, approximately $80 \%$ of the hospital staphylococcal infections are treated with glycopeptides, such as vancomycin and teicoplanin. This is still the antimicrobial class of choice for treating infections caused by MRSA, although strains with reduced sensitivity to vancomycin have already been isolated in Brazil. ${ }^{22}$

The accessory gene regulator (agr) of Staphylococcus aureus modulates the expression of numerous virulence factors in the phase-dependent growth. According to Rose et al. (2007), all agr groups develop intermediate resistance to vancomycin with subtherapeutic exposures. ${ }^{23}$

The study by Sakoulas et al. (2006) has shown that the exposure to subtherapeutic vancomycin concentrations is associated with the development of clinically hetero-GISA (glycopeptide intermediate-resistant S. aureus) isolates. These authors consider that the constant 
exposure of microorganisms to a vancomycin concentration $>10 \mathrm{mg} / \mathrm{L}$ is important in preventing the appearance of intermediate resistance to glycopeptides. ${ }^{24}$

Johnson and Woodford (2002), studying glycopeptide resistant S. aureus (GRSA), have reported that GRSA isolated in Michigan with one $v a n A$ gene, along with other genes, encode a high level of resistance to glycopeptides. ${ }^{25}$

Due to the increasing use of vancomycin, worrisome vancomycin-resistant strains of E. faecium and E. faecalis have emerged. The determinant of this resistance is located in a transposon that is part of a plasmid; thus, the vancomycin-resistant enterococcus can transfer its resistance to other Gram-positive bacteria, such as staphylococci, worsening even more the occurrence of multi-resistant bacteria. ${ }^{3}$

The GISA and GRSA resistances, although still rare, should be under constant multidisciplinary surveillance. The following patients are at risk for GISA: patients receiving prolonged vancomycin therapy; patients previously colonized by MRSA or vancomycin-resistant enterococci (VRE), particularly those with peritoneal catheters; patients with documented MRSA infection; and HD patients, who frequently have MRSA and undergo therapy with glycopeptides. ${ }^{26}$

Because VRE are usually resistant to other antibiotics commonly used in hospitals, severe exposure to other drugs is associated with a high risk of acquiring VRE. ${ }^{27}$

Similarly to beta-lactam antibiotics, vancomycin has negligible post-antibiotic effects and requires the maintenance of concentrations equivalent to four to five times MIC during prolonged periods to obtain an efficient antibacterial effect. $^{8}$

In clinical practice in Brazilian hospitals, dosing for most patients with chronic renal failure is $1 \mathrm{~g}$ every seven days. However, in a study by González-Martin et al. (1996), the vancomycin level seven days after administration was lower than expected and a subtherapeutic level was probably achieved days before. ${ }^{17}$

Zoer et al. (1997) have recommended an initial vancomycin dose of $1 \mathrm{~g}$, to which $500 \mathrm{mg}$ should be added during each subsequent HD session in patients with a positive culture for S. aureus. The ideal time for plasma monitoring would occur $48 \mathrm{~h}$, and $96 \mathrm{~h}$ or $120 \mathrm{~h}$ after vancomycin infusion..$^{18}$ Other authors have recommended the determination of vancomycin serum concentration before the first HD session subsequent to the administration and before 72 -hour of HD session. If the results are below the recommended values (between 5 and $10 \mu \mathrm{g} / \mathrm{mL}$ ), a complementary 500-mg dose of vancomycin can be used. ${ }^{5,28}$

It is worth noting that, in this study, $86 \%$ of the patients had concentrations below $10 \mu \mathrm{g} / \mathrm{mL}$ and $14 \%$ of the patients had concentrations below $5 \mu \mathrm{g} / \mathrm{mL}$. When the collection times are considered, one can infer that the number of patients reaching trough concentrations below $5 \mu \mathrm{g} / \mathrm{mL}$ would be greater. It is also worth noting that vancomycin has been administered during the HD session, but supple- mentary doses are not administered according to the recommendation of Mason et al. (2003) who have compared three regimens of vancomycin dosing.

In conclusion, the patients included in this study were exposed to antibiotic subtherapeutic doses. Considering the increased risk of selecting resistant microorganisms, monitoring of vancomycin serum concentration in HD patients is recommended.

\section{ACKNOWLEDGEMENTS}

The authors thank the support of the Nephrology Service, the nurse Yuriko Miyamoto, Edênia M. C. Fronteira, and Ivanilda S. Aquino of the Service of Hospital Infection Control and Blood Center of Conjunto Hospitalar de Sorocaba. They also thank the Instituto de Diagnóstico de Sorocaba and the Unimed Hospital de Sorocaba.

The authors also thank the CNPq for financial support (references 402722/2005-1 and 117276/2006-5).

\section{REFERENCES}

1. Klasco RK editor. Martindale: the extra pharmacopoeia. Base de dados na Internet. Greenwood Village: Thomson MICROMEDEX; 1974-2006. Disponível: http://www.periodicos.capes. gov.br. Acesso em 20 de maio de 2008.

2. Ge M, Chen Z, Onishi HR, Kohler J, Silver LL et al. Vancomycin derivatives that inhibit peptidoglycan biosynthesis without binding D-ala-D-ala. Science 1999; 284:507-10.

3. Marinho, DS Vancomicina, estudo de utilização com ênfase em suas reações adversas. 2005. 120 f. Dissertação (Mestrado) - Fundação Oswaldo Cruz, Rio de Janeiro, 2005.

4. Bartlett JG Antibiotic selection for infections involving methicillin-resistant Staphylococcus aureus. 2004. Disponível em: http://www.medscape.com/viewprogram/3124. Acesso em 03 de dezembro 2007.

5. Lentino JR, Leehey DJ. Infecções. In: Daugirdas JT, Blake PG, Ing TS. Manual de diálise. 3. ed. Rio de Janeiro: Guanabara Koogan, 2001.

6. Marcondes CRR, Biojone CR, Cherri JM, Takachi P, Carlos E. Complicações precoces e tardias em acesso venoso central: análise de 66 implantes. Acta Cirúrgica Brasileira 2007; 15:73-5.

7. Mason NA, Neudeck BL, Welage LS, Patel JA, Swartz RD. Comparison of 3 vancomycin dosage regimens during hemodialysis with cellulose triacetate dialyzers: post-dialysis versus intradialytic administration. Clinical Nephrology 2003; 60:96-104.

8. Silva LAM, Pansard HM, Rosa DB, Botton SR, Mezzomo NF et al. Níveis sanguíneos de vancomicina e adequação de seu uso em pacientes com insuficiência renal em tratamento dialítico. Jornal Brasileiro de Nefrologia 1998; 20:411-8.

9. Tavares W. Glicopeptídeos e Lipopeptídeos. In: Antibióticos e quimioterápicos para o clínico. São Paulo: Atheneu, 2007.

10. Launay-Vacher V, Izzedine H, Mercadal L, Deray G. Clinical review: use of vancomycin in haemodialysis patients. Critical Care 2002; 6(4):313-6.

11. Livornese LL, Slavin D, Gilbert B, Robbins P, Santoro J. Use of antimicrobial agents in renal failure. Infectious Disease Clinics of North America 2004; 18(3):551-79. 
12. Bingen E, Mariani-Kurkdjian P, Nebbad B. Optimal vancomycin serum level in Staphylococcus aureus infections? Medecine et Maladies Infectieuses 2006; 36(9):439-42.

13. Mandell GL, Bennett JE, Dolin R. Mandell, Douglas, and Bennett's: principles and pratice of infectious diseases. 6 ed. Philadelfia: Elsevier, 2005.

14. Stryjewski ME, Szczech LA, Benjamin DK, Inrig JK, Kanafani ZA et al. Use of vancomycin or first-generation cephalosporins for the treatment of hemodialisys-dependent patients with methicillin-susceptible Staphylococcus aureus bacteremia. Clinical Infectious Diseases 2007; 20:190-6.

15. Nielsen HE, Hansen HE, Korsager B, Skov PE. Renal excretion of vancomycin in kidney disease. Acta Medica Scandinavica 1975; 197(4):261-4.

16. Masur H, Francioli P, Ruddy M, Murray HW. Vancomycin serum levels and toxicity in chronic hemodialysis patients with Staphylococcus aureus bacteremia. Clinical Nephrology 1993; 2:85-8.

17. Gonzalez-Martin G, Acuna V, Perez C, Labarca J, Guevara A, Tagle R. Pharmacokinetics of vancomycin in patients with severely impaired renal function. International Journal of Clinical Pharmacology and Therapeutics 1996; 34(2): 71-5.

18. Zoer J, Schrander-Van Der Meer AM, Van Dorp WT. Dosage recommendations of vancomycin during haemodialysis with highly permeable membranes. Pharmacy World \& Science 1997; 19(4):191-6.

19. Foote EF, Dreitlein WB, Steward CA, Kapoian T, Walker JA, Sherman RA. Pharmacokinetics of vancomycin when administered high flux hemodialysis. Clinical Nephrology 1998; 50(1):51-5.

20. Lucksiri A, Scott MK, Mueller BA, Hamburger RJ, Sowinski KM. CAHP-210 dialyzer influence on intra-dialytic vanco- mycin removal. Nephrology Dialysis Transplantation 2002; 17(9):1649-54.

21. Goldman L, Ausiello D. Cecil: tratado de medicina interna. 22 . ed. Rio de Janeiro: Elsevier, 2005.

22. Bernardes RC, Jorge AOC, Leão MVP. Sensibilidade à oxacilina, vancomicina e teicoplanina de Staphylococcus coagulasepositivo isolados de pacientes hospitalizados de São José dos Campos. Revista Biociências 2004; 10(1-2):73-8.

23. Rose WE, Rybak MJ, Tsuji BT, Kaatz GW, Sakoulas G. Correlation of vancomycin and daptomycin susceptibility in Staphylococcus aureus infererence to accessory gene regulator (agr) polymorphism and function. Journal of Antimicrobial Chemotherapy 2007; 59:1190-3.

24. Sakoulas G, Howard SG, Cohen RA, Venkataraman L, Moellering RC, Eliopoulos GM. Effects of prolonged vancomycin administration on methicillin-resistant Staphylococcus aureus (MRSA) in a patient with recurrent bacteraemia. Journal of Antimicrobial Chemotherapy 2006; 57(4):699-704.

25. Johnson AP, Woodford N. Glycopeptide-resistant Staphylococcus aureus. Journal of Antimicrobial Chemotherapy 2002; 50:621-23.

26. Center for Disease Control and Prevention. Laboratory capacity to detect antimicrobial resistance. 1998; 48:1167-71.

27. Finch RG, Eliopoulos GM. Safety and efficacy glicopeptide antibiotics. Journal of Antimicrobial Chemotherapy 2005; 55(S2):ii5-ii13.

28. Santos CR, Feferbaum R, Paula LSA, Bertoline MA, Omosako CEK, Santos SRC. Micrométodo para quantificação da vancomicina em plasma através da cromatografia líquida de alta eficiência: monitorização plasmática de vancomicina na sustentação farmacológica de neonatos com sepse. Revista Brasileira de Ciências Farmacêuticas 2001; 37(1):87-93. 